\title{
Effect of Fish Meal (Low Value) as a Nutrient Source in Combination with Inorganic Fertilizer to Enhance the Algal Development in Fertilizer Pond
}

\author{
Nguyen Van Hoa, Tran Suong Ngoc and Dao To Nhi \\ College of Aquaculture and Fisheries, Can Tho University, Cantho 900000, Vietnam
}

\begin{abstract}
To study an application of low-value fishmeal (i.e. organic manure) and the effect of different nitrogen (N) and phosphorus $(\mathrm{P})$ ratios $\left(\mathrm{N} / \mathrm{P}_{\mathrm{s}}\right)$ to the composition of algae prevailing in fertilized ponds for culturing Artemia. Phytoplankton composition and their abundance were determined through qualitative and quantitative sampling and analyses. The experiment included five treatments, control treatment using chicken manure $\left(300 \mathrm{~g} / \mathrm{m}^{3}\right)$, the others with fishmeal in different rates (i.e. $30 \mathrm{~g} / \mathrm{m}^{3}$, $60 \mathrm{~g} / \mathrm{m}^{3}, 90 \mathrm{~g} / \mathrm{m}^{3}, 120 \mathrm{~g} / \mathrm{m}^{3}$ ) with 3 replicates each and in a combination with inorganic fertilizer. Result indicated that the algal density of the experiment varied from $318 \times 10^{3}$ to $2,590 \times 10^{3}$ cells $/ \mathrm{mL}$ and a significant difference among treatments $(p<0.05)$. The density of algae at the second treatment $\left(30 \mathrm{~g} / \mathrm{m}^{3}\right)$ is the highest with a mean density of $2,590 \times 10^{3}$ cells $/ \mathrm{mL}$. There are 38 phytoplankton species belonging to five phyla of algae, i.e. Bacillariophyta, Cyanophyta, Chlorophyta, Dinophyta and Euglenophyta. Also, there are 18 species of Bacillariophyta, 14 species of Chlorophyta, 4 species of Cyanophyta, 1 species of Dinophyta and 1 species of Euglenophyta. Algae compositions were 32, 34, 31, 27 species at control treatment, and $30 \mathrm{~g} / \mathrm{m}^{3}, 60 \mathrm{~g} / \mathrm{m}^{3}, 90 \mathrm{~g} / \mathrm{m}^{3}, 120$ $\mathrm{g} / \mathrm{m}^{3}$ fishmeal treatments, respectively. The dominant genus was usually Nitzschia, Thalassiosira, Navicula (Bacillariophyta), Tetraselmis (Chlorophyta), Oscillatoria (Cyanophyta), Euglena (Euglenophyta). Euglena usually appeared in the late phase of the experiment.
\end{abstract}

Key words: Fishmeal, phytoplankton, fertilizer pond.

\section{Introduction}

Artemia is an excellent live food which meets the nutritional requirement of most of shrimp/fish larvae [1-4], therefore a number of studies have been done on Artemia biology, growth, nutritional value and reproduction of Artemia. Artemia as non-filter feeder they could filter organic matter, bacteria, micro algae...as far as their size less than $50 \mu \mathrm{m}$ [5-7]. Artemia population in natural environment depends on micro algae as live food [8]. Therefore, microalgae being considered as a food item for Artemia have been intensively studied. In Vinhchau coastal area, there are 5 common phyla of phytoplankton to be indicated such as: Bacillariophyta, Cyanophyta, Chlorophyta, Chrysophyta, Rhodophyta [9]. In fertilizer pond, there

Correspondence: Nguyen Van Hoa, Ph.D., associate professor, research field: aquaculture. are unwanted species that occur which are not digestible by Artemia, therefore it is necessary to control these species both in skill or by the experience of being a farmer or technician rather than a reliable protocol. In fact, they were possibly controlled by applying different fertilizer which may affect their nutritional requirement.

Chicken manure is the common organic manure that is used as direct food or to bring up nutrients (i.e. nitrogen and phosphate) for fertilizer pond of Artemia culture system. However, the "bird-flu" occurred since 2003 and there were few cases that man were infected with H5N1 virus. The bloom of bird-flu in 2005 quickly spread over $33 / 63$ provinces in Vietnam, as a result, almost 1.2 million of poultry were burned down. Due to the disease, it was recorded there were over 140 million poultry that went down or were incinerated. According to WTO (World Trade 
Organization) in the WHOWPRO (World Health Organization Western Pacific Regional Office) from 2003 to 2015 there were 127 people infected with H5N1 and 64 died in Vietnam. It is therefore, necessary to find out a possible replacement of chicken manure for Artemia farming. Also, it is known that the manure from quail, duck or pig farm are also available for Artemia farming [10], however, these are not commonly used as they may stimulate the development of filamentous algae, which are not suitable for Artemia filtration (ingestion). Fish meal (low value) contents have a high concentration of protein and phosphate can be used in agriculture locally for vegetation to be considered as organic manure to replace chicken manure for Artemia farming. The combination of fish meal and fertilizer that is designed for fertilizer pond supports the algae development in terms of composition and concentration/density will be discussed.

\section{Materials and Methods}

This study was conducted in the Vinhchau field station, Soctrang province (Mekong Delta).

Materials: chicken manure, fish meal (low value), urea, DAP (diammonium phosphate), phytoplankton net (mesh size: $25-30 \mu \mathrm{m})$, basket, pet bottles $(1 \mathrm{~L})$, graduated cylinder $100 \mathrm{~mL}$, formalin (38-40\%), microscope, Bürker chamber, pipet, lame and lamella; thermometer, refractometer, Secchi disc, scale, screening and refrigerator.

Effect of fish meal (low value) in combination with fertilizer to enhance the algal development in fertilizer pond was conducted. Experiment was set-up with 5 treatments (three replicate each) including (1) The control: $300 \mathrm{~g} / \mathrm{m}^{3}$ chicken manure; (2) Treatment 1 (NT 30): $30 \mathrm{~g} / \mathrm{m}^{3}$ fish meal; (3) Treatment 2 (NT 60): $60 \mathrm{~g} / \mathrm{m}^{3}$ fish meal; (4) Treatment 3 (NT 90): $90 \mathrm{~g} / \mathrm{m}^{3}$ fish meal; and (5) Treatment 4 (NT 120): $120 \mathrm{~g} / \mathrm{m}^{3}$ fish meal, respectively. The same amount of fertilizer was $6 \mathrm{~g} / \mathrm{m}^{3}$ of urea (46\%) and diammonium phosphate $(\mathrm{N}: \mathrm{P}: \mathrm{K}=18: 46: 0)$ in the ratio of $\mathrm{N}: \mathrm{P}=5: 1$ by weight will be added for all treatments. The experiment was conducted in 15 earthen ponds with $150 \mathrm{~m}^{2}$ each, water depth $50 \mathrm{~cm}$, and salinity at $31 \%$. The experiment lasted for 12 days (till the algae collapsed).

\subsection{Pond Preparation}

Prior setting up the experiment, the ponds were excavated and dried to the bottom between 2-3 days. There was a removal of predators by saponin (at the dose of $15 \mathrm{mg} / \mathrm{L}$ ) in order to eliminate the small crustacean. This activity was conducted at noon time or early afternoon (at high temperature) in order to enhance the effect of saponin. A day before the experiment commenced, fresh sea-water was filled into the ponds via screening of $1 \mathrm{~mm}$ to prevent trash fishes and predators.

\subsection{Fertilization}

The total amount of urea and DAP was $6 \mathrm{~g} / \mathrm{m}^{3}$, in which: urea was accounted for $4.93 \mathrm{~g}$, DAP $1.07 \mathrm{~g}$ with a ratio of $\mathrm{N}: \mathrm{P}=5: 1$. Periodical fertilizer was at day 1 , day 4 , day 7 and day 10 of the experiment. Chicken manure and fish meal were fertilized once per week and in day 1 and day 7 of the experiment.

\subsection{Parameter Monitoring}

\subsubsection{Quantitative Sampling}

Sampling was carried out in the pond corners and the middle one, there were 2 litters each, then mixing well prior to take a sub-sample of one liter and preserved by $2-4 \%$ formaldehyde. Pond sampling was conducted at $8 \mathrm{am}$.

\subsubsection{Qualitative Sampling}

Qualitative samples: sampling was carried out every 3-day interval by using phytoplankton net (mesh size 25-30 $\mu \mathrm{m}$ ), scoop-net with round shape, and sampling by pushing the sampling net in zig-zag. After sampling, algae stuck on the net to be washed and accumulated into the bottle attached beneath. Algae samples were collected and stored in bottles preserved 
with formaldehyde $2-4 \%$.

\subsubsection{Chemical Samples}

There was a sampling of a litter of water for quantitative sampling and to keep the sample at $4{ }^{\circ} \mathrm{C}$. Periodical sampling every 3 days for environmental parameters i.g. TA (Total Ammonia Nitrogen), $\mathrm{NO}_{3}{ }^{-}$, $\mathrm{PO}_{4}{ }^{3-}, \mathrm{TN}$ (Total Nitrogen), TP (Total Phosphorous), chlorophyll $a$ was implemented. For chlorophyll $a$ analysis water sample was filtered in the field station and analysis was carried out in the chemical laboratory.

\subsubsection{Analytical Methodology}

Quantitative sample: Algae were counted under a microscope with the Bürker chamber. Counting protocol and calculation of algal density followed [11].

\section{Number of cell $/ \mathrm{mL}=\left(\left(n_{1}+n_{2}\right) / 160\right) \times 10^{6} \times d$}

in which $n_{1}$ : number of cells in upper chamber; $n_{2}$ : number of cells in lower chamber; and $d$ : dilution factor Qualitative sample: Collected samples after settling will be used for observation under a microscope with a magnification of $40 \times$ in order to classify the number of species. Then a photo was taken, to describe their morphological, size measurement and identification.

Appearance frequency followed the scale of Cheffer and Robinson [12], in which $>60 \%$ means a lot of/so many $(+++)$; 30-60\%: many $(++)$; and $<30 \%$ : seldom $(+)$.

Water parameters for environment as TAN were measured by Phenate method while $\mathrm{PO}_{4}{ }^{3-}$ was $\mathrm{SnCl}_{2}$ method [13]; $\mathrm{NO}_{3}{ }^{-}$: to follow sulfosalicylic acid method; TN: Macro-Kjeldahl method and TP: Macro-Kjeldahl method (TKN (Total Kjeldahl Nitrogen), TP (Total Phosphorus) water sample); Chlorophyll $a$ : colorimetric analysis by color spectrum [14], and extraction by acetone.

Other parameters such as temperature, were measured by thermometer and measured twice per day at 7 am and $2 \mathrm{pm}$; The salinity was recorded by refractometer and measured once per day at $7 \mathrm{am}$;
Turbidity was measured by Secchi-disc and measured once per day at $2 \mathrm{pm}$; and the $\mathrm{pH}$ was recorded by $\mathrm{pH}$ meter and was measured every three days at $7 \mathrm{am}$.

Data analysis was calculated and the mean and the standard deviation by spreadsheet. The Duncan test in Statistica version 7 to compare statistically among treatments at significant level of $p<0.05$ was applied.

\section{Results and Discussion}

\subsection{Water Quality}

\subsubsection{Temperature}

The average temperatures at 7 am in the control, NT30, NT60, NT90, NT120 were $26.2 \pm 0.7,26.1 \pm$ $0.6,26.1 \pm 0.7,26.1 \pm 0.6$ and $26.0 \pm 0.5{ }^{\circ} \mathrm{C}$, respectively. And at $2 \mathrm{pm}$ recorded temperature were $31.6 \pm 0.1,31.2 \pm 0.0,31.2 \pm 0.2$ and $31.3 \pm 0.2{ }^{\circ} \mathrm{C}$, respectively. In general, the average temperatures of different treatments are not statistically different $(p>$ 0.05). Although the temperature in the afternoon was a bit higher than the optimal temperature most were not affected. The outdoor condition with high temperature combined with more sunshine to stimulate the photosynthesis of algae.

According to Coutteau [11], the optimal temperature for phytoplankton varies in the range of 20-24 ${ }^{\circ} \mathrm{C}$, and each algal species has its own optimal temperature. Below $16{ }^{\circ} \mathrm{C}$, the growth of algae is retarded, over $35^{\circ} \mathrm{C}$ most of the algae will collapse.

\subsubsection{Salinity}

The average salinities of the control and treatments of NT30, NT60, NT90, NT120 were $34.0 \pm 2.8,33.7$ $\pm 2.2,34.9 \pm 2.8,34.9 \pm 2.7$ and $34.3 \pm 2.2 \%$, respectively. The initial salinity of the seawater was $31 \%$, but it increased gradually due to evaporation and less than 40\%o when the experiment ended, however, it was not harmful to the algae (Fig. 1).

According to Coutteau [11], optimal salinity for algae varies around 20-24\%, however, marine algae could stand with salinity variation. Nonetheless, algae grow better at salinity as similar as to where they appear. 


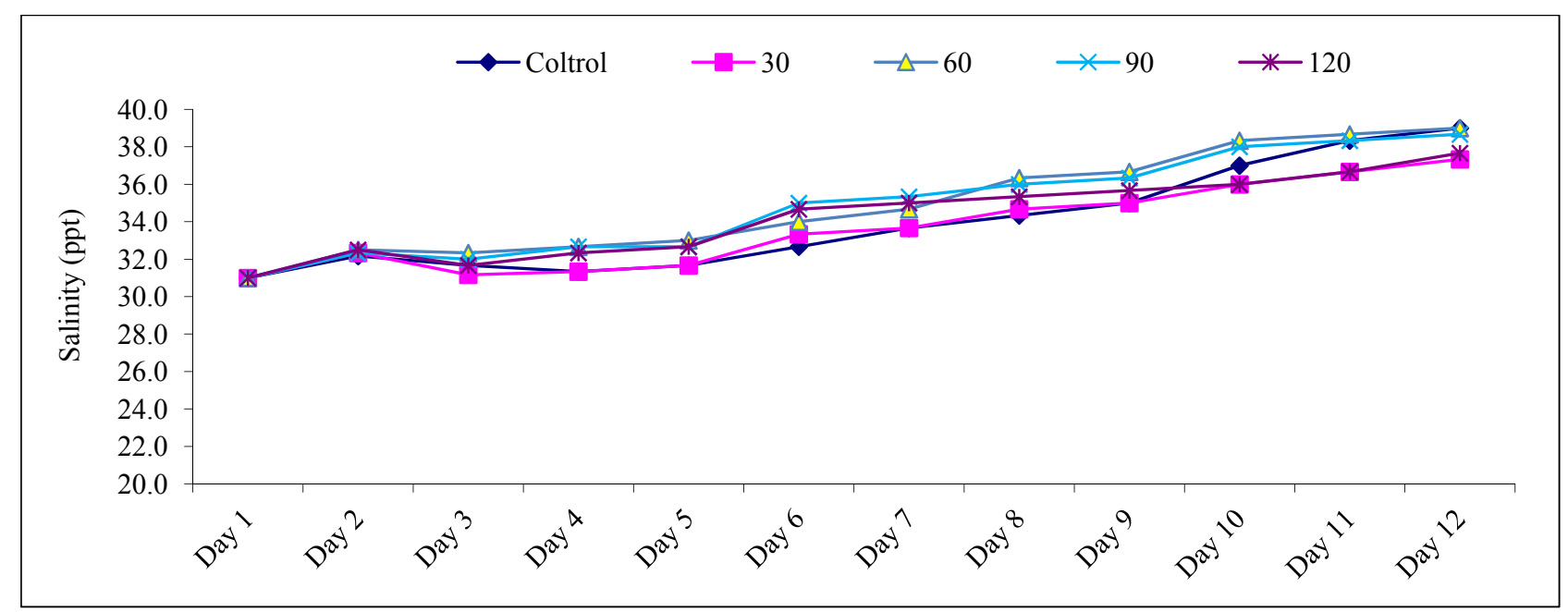

Fig. 1 Variation of average salinity.

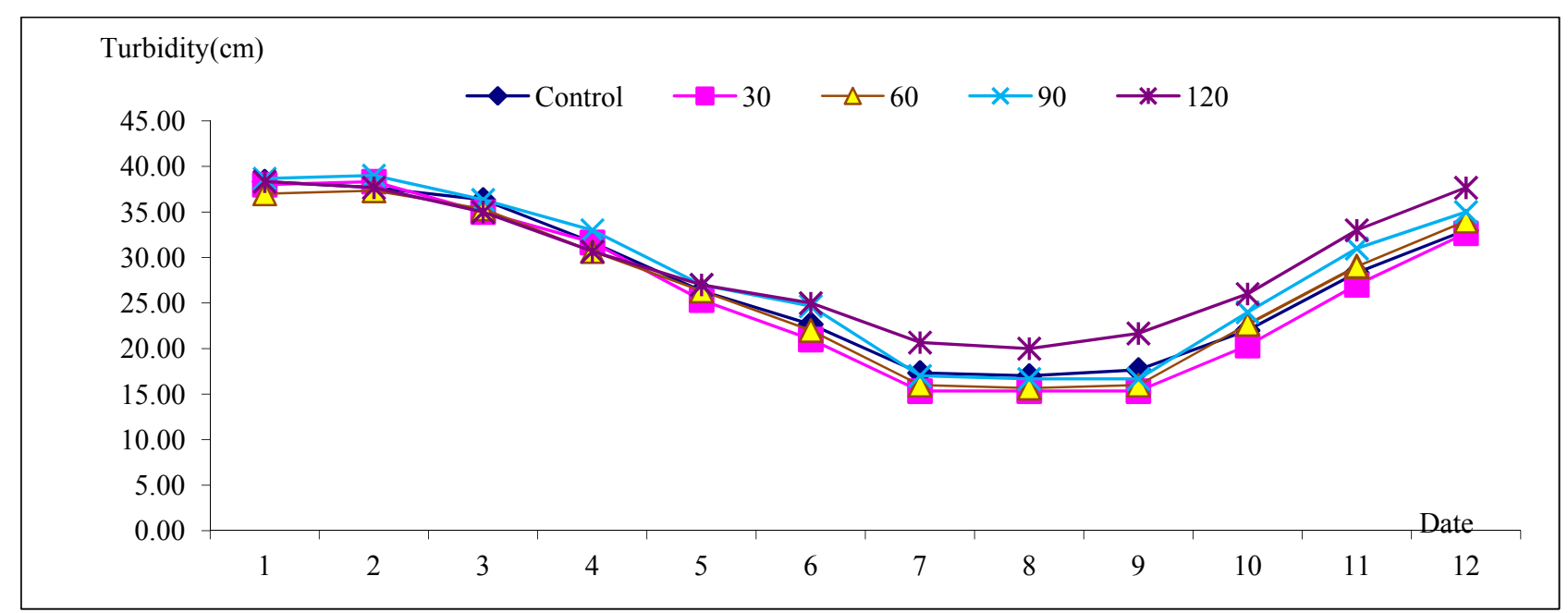

Fig. 2 Variation of average turbidity.

\subsubsection{Turbidity}

The average turbidities of the control and different treatments were $28.8 \pm 11.0,27.7 \pm 11.7,28.3 \pm 11.4$, $29.6 \pm 11.2$ and $30.8 \pm 9.9 \mathrm{~cm}$, respectively. Fig. 2 shows turbidity declined right after the first day since set-up and it lasted until day 8 , then it increased from day 9 afterward. In matching with Fig. 2, there is relationship between turbidities and algal densities (i.e. low turbidity engaged to high algal densities and vice versa).

\section{$3.1 .4 \mathrm{pH}$}

The average $\mathrm{pH}$ of different treatments increased from day 1 to day 7, however, variation is negligible and prolongs until the end of the experiment. High $\mathrm{pH}$ was recorded due to normally heavy photosynthesis occurring, algae take in $\mathrm{CO}_{2}$ more than release due to respiration, and thus extra $\mathrm{CO}_{2}$ is needed from $\mathrm{HCO}_{3}^{-}$ transformation and thus to release more carbonate to accelerate $\mathrm{pH}$ level.

The average $\mathrm{pH}$ of the control and treatments was $8.5 \pm 0.2,8.6 \pm 0.2,8.7 \pm 0.2,8.6 \pm 0.2$ and $8.7 \pm 0.3$, respectively. In general, $\mathrm{pH}$ was in a range of 7-9 and was suitable for algal development.

According to Coutteau [11], the appropriate $\mathrm{pH}$ range of $\mathrm{pH}$ for most of the algal species is about 7-9, and the optimal range is 8.2-8.7. The $\mathrm{pH}$ in the environment affects the growth and metabolism of the cell, and this happens to the algae also, therefore $\mathrm{pH}$ 
plays an important role in algal development. In the opposite algae, when overdeveloped (e.g. water bloom), will increase the $\mathrm{pH}$ and slow down the algae development.

\subsubsection{N-NH${ }_{4}^{+}$(TAN)}

$\mathrm{N}-\mathrm{NH}_{4}{ }^{+}$concentration increased gradually after 3-day fertilization. It was declining at day 7 but then increased again till the end of the experiment. At days 4, 7 and 10, fertilizers were supplied (routine works) and helped to stabilize $\mathrm{N}-\mathrm{NH}_{4}{ }^{+}$levels although algae in higher concentration. At day 10, algae collapsed, therefore $\mathrm{N}_{-} \mathrm{NH}_{4}{ }^{+}$remained at a high level (Fig. 3).

Concentrations of $\mathrm{N}^{-\mathrm{NH}_{4}}{ }^{+}$in the control and all treatments from ĐC, NT30, NT60, NT90, NT120 were $1.98 \pm 1.3,2.01 \pm 1.3,1.84 \pm 1.4,1.71 \pm 1.2$ and $2.62 \pm 1.7 \mathrm{mg} / \mathrm{L}$, respectively. The treatment of NT120 with the highest $\mathrm{N}-\mathrm{NH}_{4}{ }^{+}$at day 10 (i.e. $3.66 \pm$ $0.21 \mathrm{mg} / \mathrm{L}$ ) was related to the added fertilizer for this treatment.

In general, ${\mathrm{N}-\mathrm{NH}_{4}}^{+}$is an important nutritional component for algal development, therefore as algae is in development, this component has been absorbed intensively and thus declines afterward.

\section{$3.1 .6 \mathrm{~N}^{-N^{-}}{ }^{-}$}

There was an influence of experiment with low $\mathrm{N}^{-\mathrm{NO}_{3}}{ }^{-}$concentration (i.e. $0.13 \mathrm{mg} / \mathrm{L}$ ), but 3 days after fertilization, $\mathrm{N}^{-\mathrm{NO}_{3}}{ }^{-}$increased but slowed down when algae started to develop. Average concentrations of $\mathrm{N}-\mathrm{NO}_{3}{ }^{-}$in the control and treatments of NT30, NT60, NT90, NT120 were $0.75 \pm 0.5,0.64 \pm 0.4,0.79$ $\pm 0.5,1.01 \pm 0.7$ and $1.14 \pm 0.8 \mathrm{mg} / \mathrm{L}$, respectively (Fig. 4) in which NT120 had the highest concentration (i.e. $1.89 \pm 0.2 \mathrm{mg} / \mathrm{L}$ ). There was non-significant difference among treatments $(p<0.05)$ from day 4 of the experiment.

The variation of $\mathrm{N}^{-\mathrm{NO}_{3}}{ }^{-}$among different treatments was due to different development of algae as well as the rate of fertilization added among treatments.

3.1.7 $\mathrm{P}-\mathrm{PO}_{4}{ }^{3-}$

The average concentrations of $\mathrm{P}_{-} \mathrm{PO}_{4}{ }^{3-}$ of the control and other treatments as NT30, NT60, NT90, NT120 were $0.28 \pm 0.1,0.2 \pm 0.1,0.24 \pm 0.1,0.31 \pm$ 0.2 and $0.32 \pm 0.2 \mathrm{mg} / \mathrm{L}$, respectively (Fig. 5). There was significant difference $(p<0.05)$ of $\mathrm{P}_{-} \mathrm{PO}_{4}{ }^{3-}$ among treatments from day 4 afterward. The difference is related to the trash fish applied as beside the $\mathrm{N}$-source which is also P-source, and actually, the $\mathrm{P}$ contents increased according to the trash fish used. The concentration of $\mathrm{P}_{-} \mathrm{PO}_{4}{ }^{3-}$ tended to increase at the end of the experiment due to the decline of algae at the end.

\subsubsection{TN}

The average concentrations of $\mathrm{TN}$ of the control and other treatments as NT30, NT60, NT90, NT120 were $9.30 \pm 6.0,5.96 \pm 3.8,7.78 \pm 4.3,8.97 \pm 5.2$ and $11.09 \pm 6.8 \mathrm{mg} / \mathrm{L}$, respectively (Fig. 6) in which the

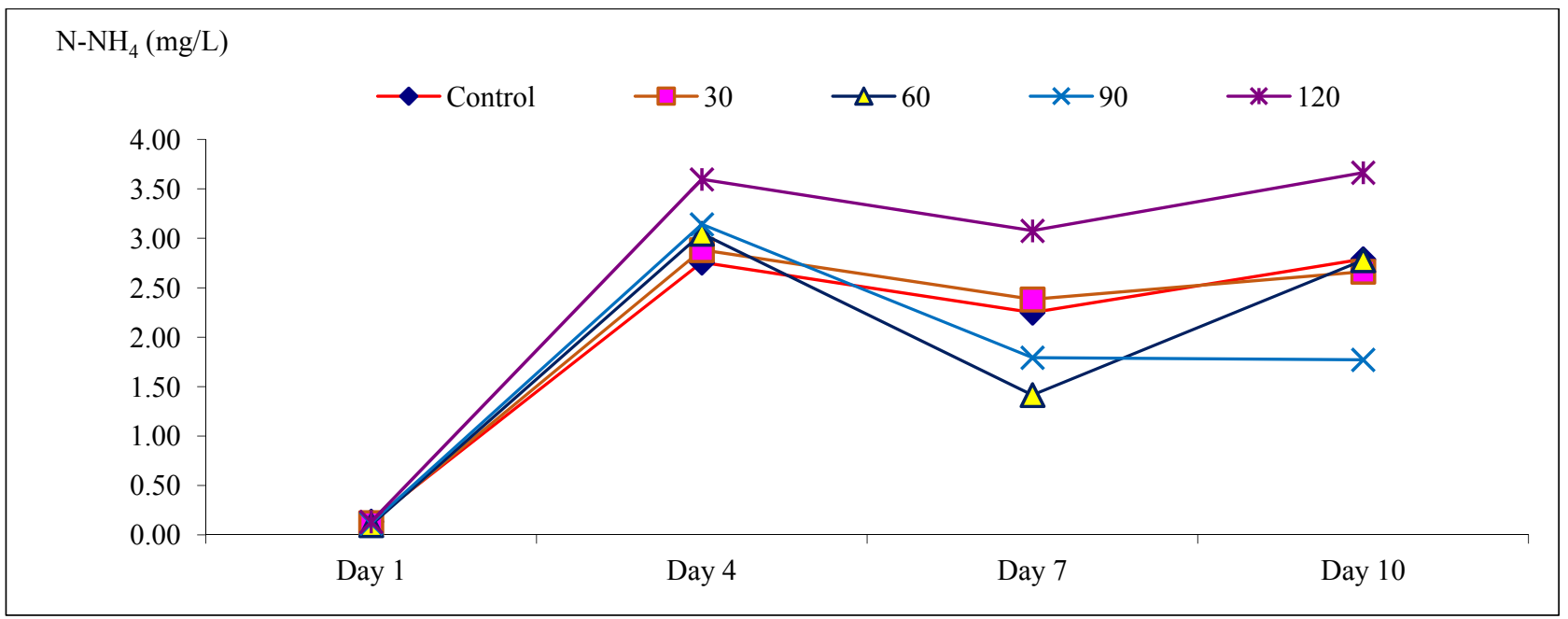

Fig. 3 Variation of an average $\mathrm{N}-\mathrm{NH}_{4}^{+}$. 

Fertilizer to Enhance the Algal Development in Fertilizer Pond

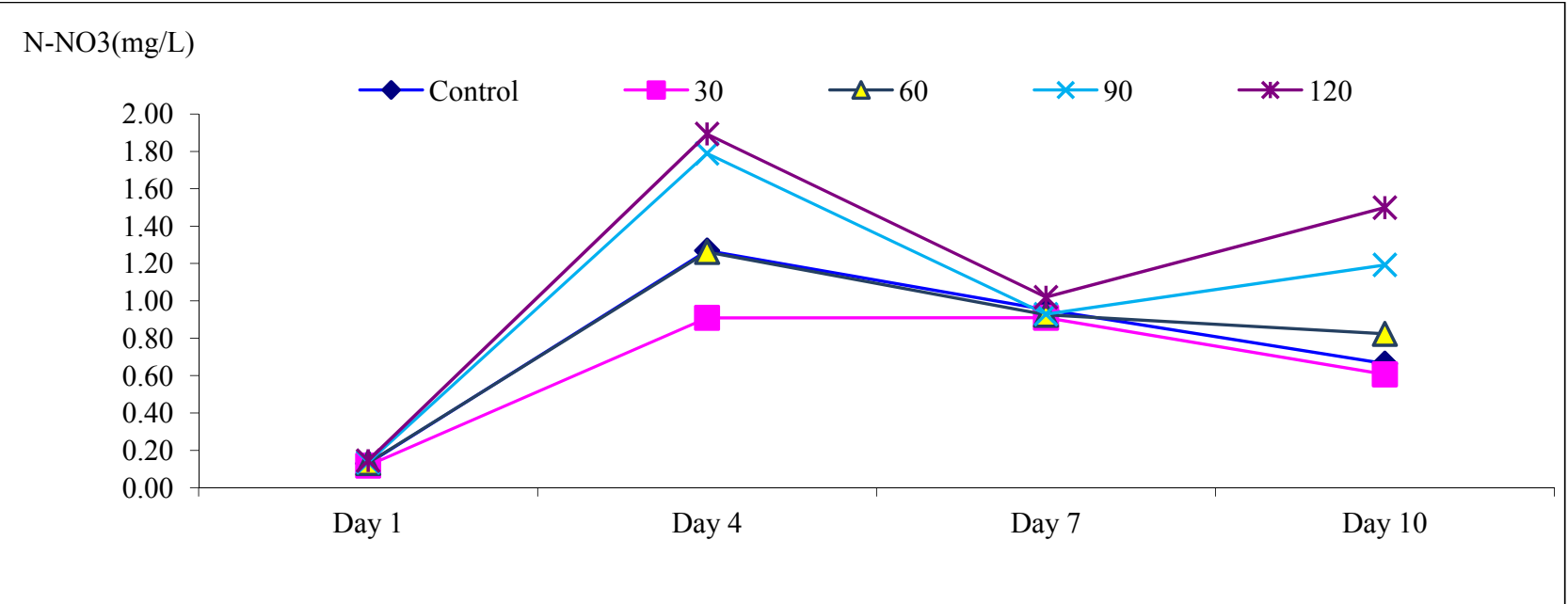

Fig. 4 Variation of an average $\mathrm{N}^{-\mathrm{NO}_{3}}$.

$\mathrm{PO}_{4}(\mathrm{mg} / \mathrm{L})$

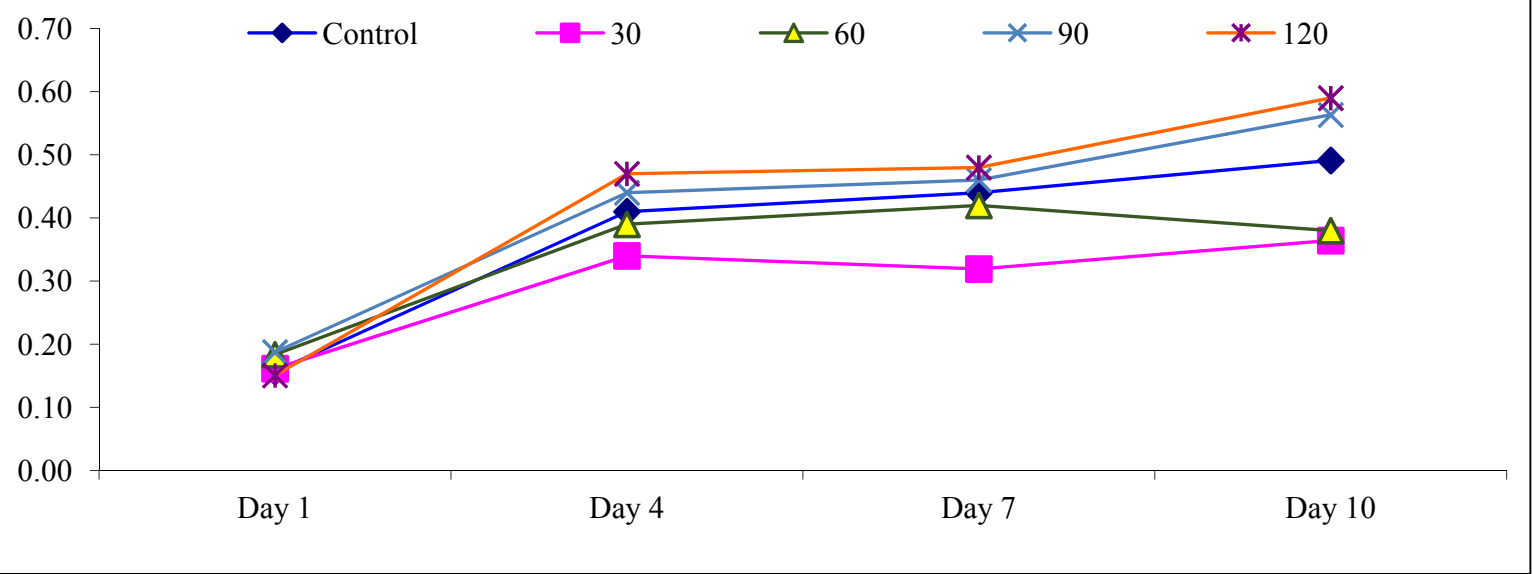

Fig. 5 Variation of $\mathrm{PO}_{4}$ among the treatments.

PO4 (mg/L)

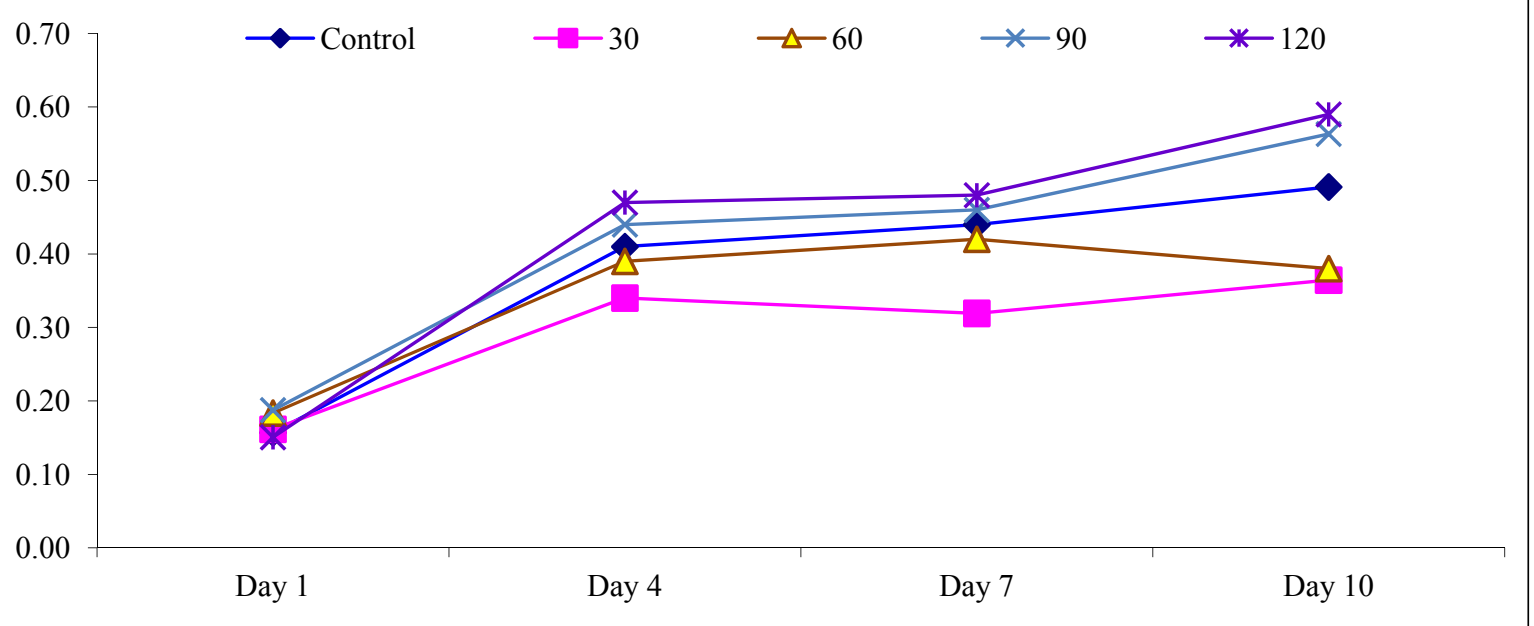

Fig. 6 Variation of total nitrogen (TN) among the treatments. 


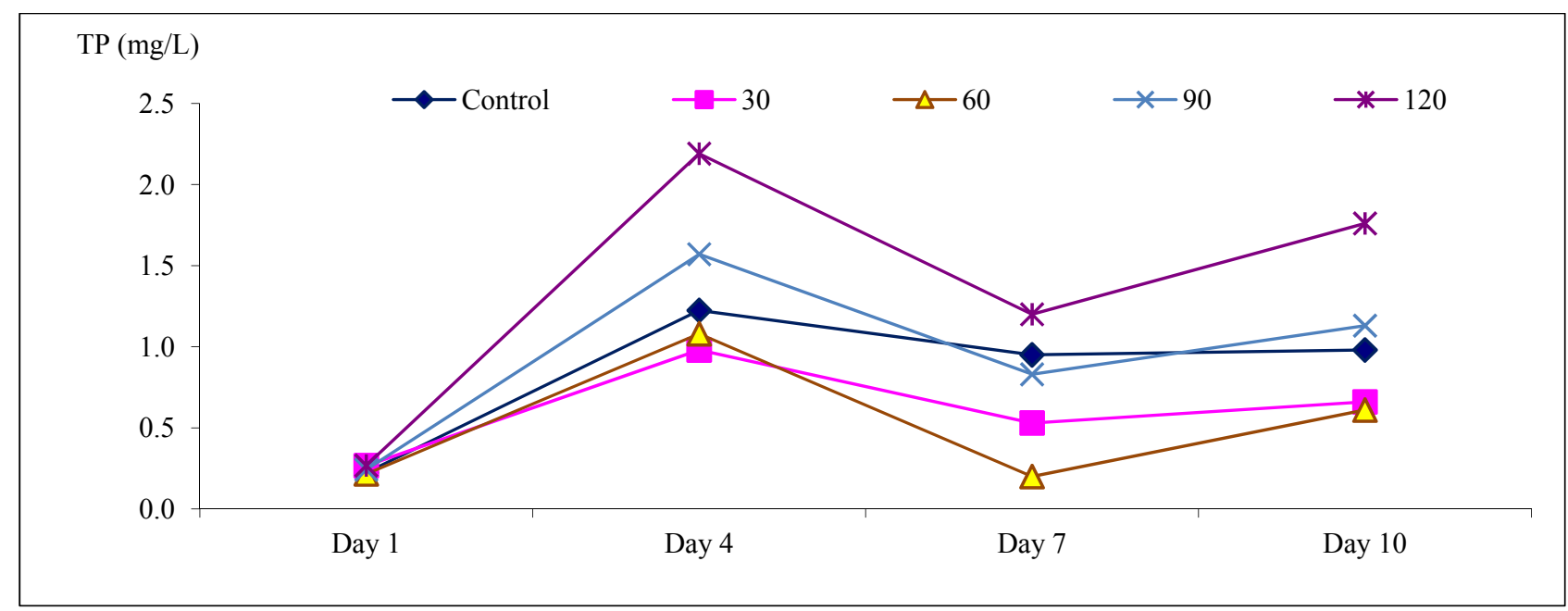

Fig. 7 Variation of TP in the experiment.

treatment with the highest average TN was NT120 (i.e. $17.2 \pm 1.1 \mathrm{mg} / \mathrm{L})$. The concentration of TN decreased at day 7 due to algal density that was highest, moreover to the end of the experiment, the $\mathrm{TN}$ was also increased as algae was in the collapsed stage.

\subsubsection{TP}

The average TP of the control NT30, NT60, NT90, $\mathrm{NT} 120$ was $0.84 \pm 0.4 \mathrm{mg} / \mathrm{L}, 0.61 \pm 0.3 \mathrm{mg} / \mathrm{L}, 0.53 \pm$ $0.4 \mathrm{mg} / \mathrm{L}, 0.94 \pm 0.6 \mathrm{mg} / \mathrm{L}$ and $1.35 \pm 0.8 \mathrm{mg} / \mathrm{L}$, respectively. The treatment of NT120 had the highest value. At day 7, the TP of all treatments declined due to algae having the utmost development, at day 10, TP was increased negligibly as algae collapsed (Fig. 7).

\subsection{Algae Development and Composition}

\subsubsection{Chlorophyll- $a$}

The average chlorophyll $a$ of the control NT30, NT60, NT90, NT120 were $53.1 \pm 23.1 \mu \mathrm{g} / \mathrm{L}, 61.2 \pm$ $29.3 \mu \mathrm{g} / \mathrm{L}, 55.1 \pm 27.4 \mu \mathrm{g} / \mathrm{L}, 56.4 \pm 20.0 \mu \mathrm{g} / \mathrm{L}$ and $55.9 \pm 19.2 \mu \mathrm{g} / \mathrm{L}$, respectively (Fig. 8). The two treatments NT30 and NT60 displayed higher content of chlorophyll compared to the others.

Fig. 8 displayed the highest chlorophyll- $a$ at day 7 , coinciding with the maximal algal density recorded; this is to explain the highest chlorophyll $a$ content related to the maximal biomass recorded [15].

\subsubsection{Algal Density}

Variation of algal density depended on nutritional contents provided to appropriate treatment.

In Table 1, to display the maximal densities of algae in the control, NT30, NT60, NT90, NT120 were $2.30 \pm 0.02 \times 10^{6}$ cells $/ \mathrm{mL}, 2.59 \pm 0.03 \times 10^{6}$ cells $/ \mathrm{mL}$, $2.56 \pm 0.05 \times 10^{6}$ cells $/ \mathrm{mL}, 2.02 \pm 0.24 \times 10^{6}$ cells $/ \mathrm{mL}$ and $1.92 \pm 0.17 \times 10^{6}$ cells $/ \mathrm{mL}$, respectively. Treatment NT30 displayed the highest density (i.e. $2.59 \pm 0.03 \times 10^{6}$ cells $/ \mathrm{mL}$ ) at day 9 . In general, the rhythm of algal development lasted 12 days in the field (Fig. 9), in which the highest algal densities of different treatments occurred during day 7 to day 9 . Both chicken manure and fish meal (low value) supported algal growth as nutritional resources, in which treatment NT30 displayed the highest algal density.

\subsubsection{Phytoplankton Composition}

There are 5 phyla to be recorded which included diatom (Bacillariophyta), blue-green (Cyanophyta), green (Chlorophyta), dynoflagellate (Dinophyta) and euglena (Euglenophyta) (Fig. 10). The total number of species is 38 , in which diatom occupied 18 species (46\%), then green algae accounted for 14 species (37\%), blue-green with 4 species (11\%), dinoflagellate and euglena presented only 1 species (3\%).

Nguyen, et al. [16] observed the algal composition and density in different salinity under the biofloc system, through which at $35 \%$ there were 44 species found, and diatom was dominant with 22 species (app. 


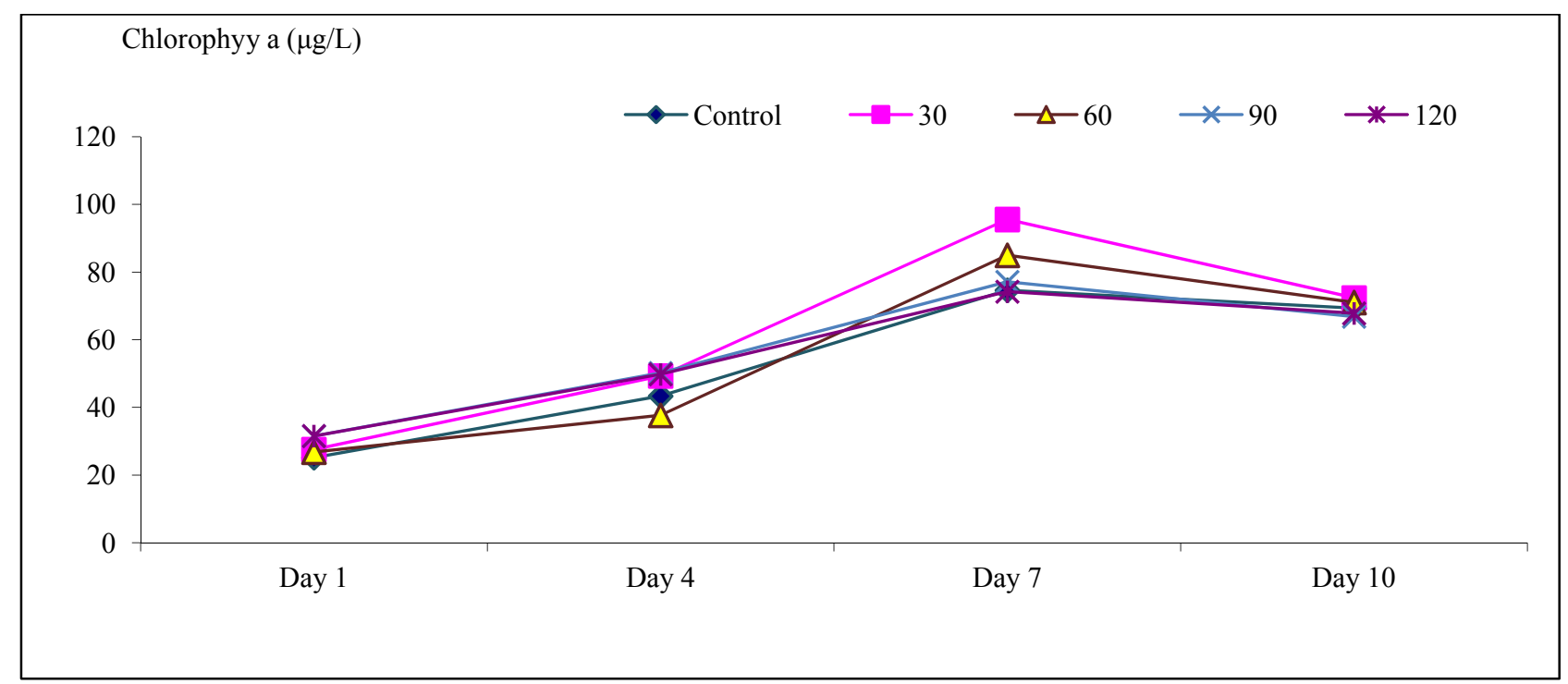

Fig. 8 Variation of chlorophyll $a$ in the experiment.

Table 1 The mean algal density $\left(\times 10^{6}\right.$ cells $\left./ \mathrm{mL}\right)$ in the experiment.

\begin{tabular}{|c|c|c|c|c|c|}
\hline Day & Control & NT30 & NT60 & NT90 & NT120 \\
\hline 1 & $0.54 \pm 0.01^{\mathrm{a}}$ & $0.55 \pm 0.01^{\mathrm{a}}$ & $0.56 \pm 0.01^{\mathrm{a}}$ & $0.55 \pm 0.02^{\mathrm{a}}$ & $0.54 \pm 0.01^{\mathrm{a}}$ \\
\hline 2 & $0.72 \pm 0.02^{\mathrm{a}}$ & $0.81 \pm 0.02^{\mathrm{b}}$ & $0.71 \pm 0.03^{\mathrm{a}}$ & $0.76 \pm 0.02^{\mathrm{ab}}$ & $0.81 \pm 0.04^{\mathrm{b}}$ \\
\hline 3 & $1.18 \pm 0.07^{\mathrm{b}}$ & $1.05 \pm 0.02^{\mathrm{a}}$ & $1.04 \pm 0.03^{\mathrm{a}}$ & $1.22 \pm 0.04^{\mathrm{b}}$ & $1.08 \pm 0.04^{\mathrm{a}}$ \\
\hline 4 & $1.16 \pm 0.07^{\mathrm{b}}$ & $1.03 \pm 0.02^{\mathrm{a}}$ & $1.05 \pm 0.05^{\mathrm{a}}$ & $1.24 \pm 0.03^{\mathrm{c}}$ & $1.00 \pm 0.04^{\mathrm{a}}$ \\
\hline 5 & $1.23 \pm 0.05^{\mathrm{a}}$ & $1.70 \pm 0.04^{\mathrm{c}}$ & $1.62 \pm 0.12^{\mathrm{c}}$ & $1.38 \pm 0.08^{b}$ & $1.24 \pm 0.04^{\mathrm{a}}$ \\
\hline 6 & $1.83 \pm 0.06^{\mathrm{c}}$ & $2.04 \pm 0.02^{\mathrm{d}}$ & $1.79 \pm 0.05^{\mathrm{c}}$ & $1.34 \pm 0.04^{\mathrm{a}}$ & $1.67 \pm 0.05^{\mathrm{b}}$ \\
\hline 7 & $2.13 \pm 0.19^{b c}$ & $2.44 \pm 0.34^{\mathrm{c}}$ & $2.51 \pm 0.16^{\mathrm{c}}$ & $1.68 \pm 0.02^{\mathrm{a}}$ & $1.92 \pm 0.17^{\mathrm{ab}}$ \\
\hline 8 & $2.30 \pm 0.02^{\mathrm{b}}$ & $2.55 \pm 0.22^{\mathrm{b}}$ & $2.56 \pm 0.05^{\mathrm{b}}$ & $2.00 \pm 0.24^{\mathrm{a}}$ & $1.79 \pm 0.08^{\mathrm{a}}$ \\
\hline 9 & $2.23 \pm 0.06^{\mathrm{c}}$ & $2.59 \pm 0.03^{\mathrm{d}}$ & $2.41 \pm 0.06^{\mathrm{cd}}$ & $2.02 \pm 0.24^{\mathrm{b}}$ & $1.81 \pm 0.01^{\mathrm{a}}$ \\
\hline 10 & $1.33 \pm 0.10^{\mathrm{a}}$ & $1.99 \pm 0.05^{\mathrm{c}}$ & $1.55 \pm 0.05^{\mathrm{b}}$ & $1.23 \pm 0.09^{\mathrm{a}}$ & $1.24 \pm 0.01^{\mathrm{a}}$ \\
\hline 11 & $0.90 \pm 0.03^{b c}$ & $0.96 \pm 0.08^{\mathrm{c}}$ & $0.84 \pm 0.05^{\mathrm{b}}$ & $0.68 \pm 0.05^{\mathrm{a}}$ & $0.64 \pm 0.03^{\mathrm{a}}$ \\
\hline 12 & $0.81 \pm 0.06^{\mathrm{d}}$ & $0.59 \pm 0.02^{\mathrm{c}}$ & $0.45 \pm 0.03^{b}$ & $0.41 \pm 0.02^{\mathrm{b}}$ & $0.32 \pm 0.03^{\mathrm{a}}$ \\
\hline
\end{tabular}

The value in row with the same letter is not significantly different $(p>0.05)$.

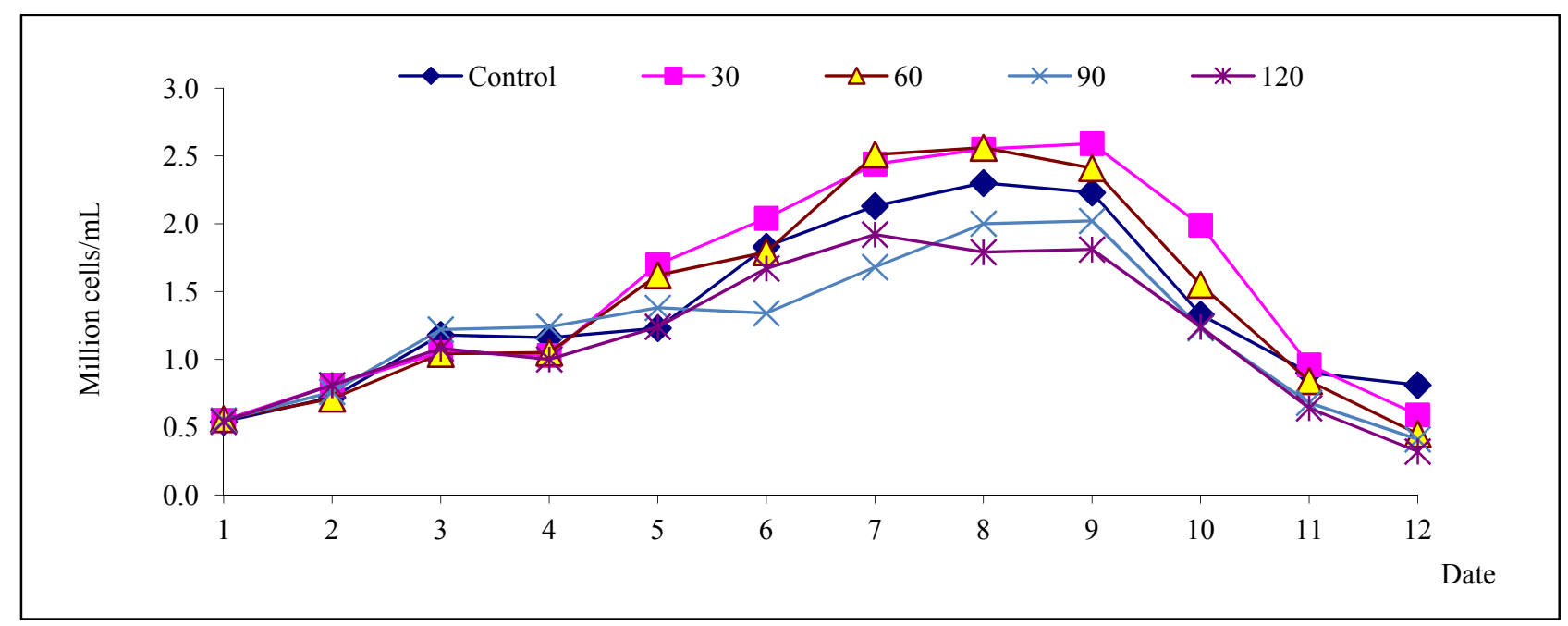

Fig. 9 Variation of algal density in the experiment. 


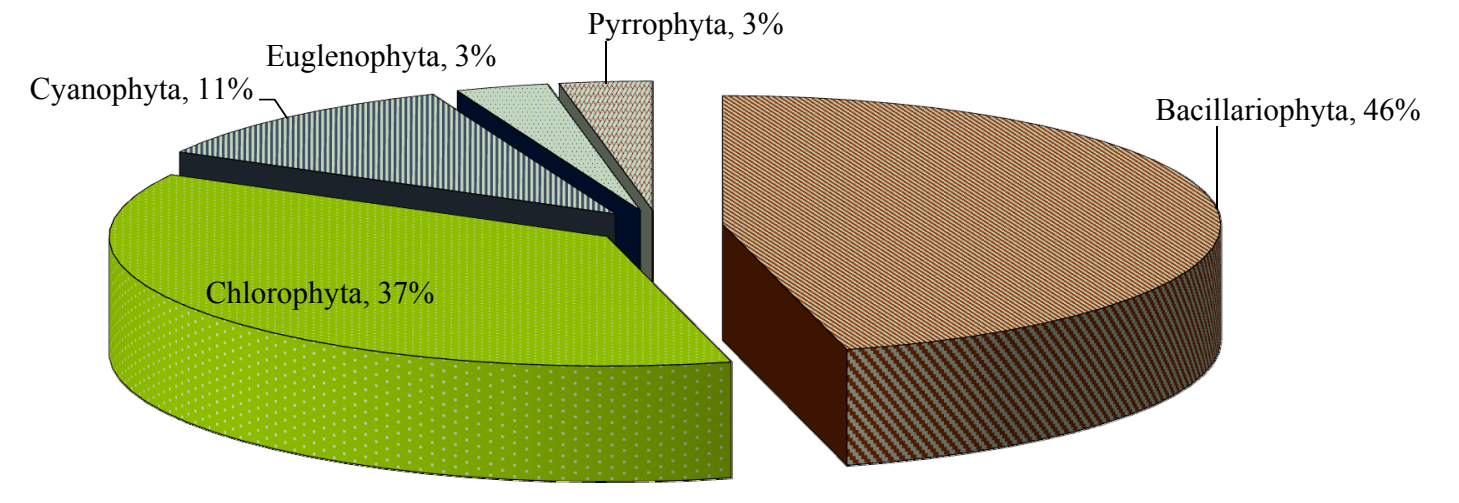

Fig. 10 Algal composition of the experiment.

Table 2 Algal species of different phylum in the experiment.

\begin{tabular}{lllllllllll}
\hline \multirow{2}{*}{ Phyla } & \multicolumn{1}{c}{ Treatment } \\
\cline { 2 - 12 } & Control & \multicolumn{1}{c}{ NT30 } & \multicolumn{1}{c}{ NT60 } & NT90 & \multicolumn{2}{c}{ NT120 } \\
\cline { 2 - 12 } & Species & $\%$ & Species & $\%$ & Species & $\%$ & Species & $\%$ & Species & $\%$ \\
\hline Bacillariophyta & 16 & 47.1 & 17 & 53.1 & 16 & 47.1 & 14 & 45.2 & 9 & 33.3 \\
Chlorophyta & 12 & 35.3 & 11 & 34.4 & 12 & 35.3 & 13 & 41.9 & 14 & 51.9 \\
Cyanophyta & 4 & 11.8 & 3 & 9.4 & 4 & 11.8 & 3 & 9.7 & 3 & 11.1 \\
Dinophyta & 1 & 2.9 & 0 & 0.0 & 1 & 2.9 & 0 & 0.0 & 0 & 0.0 \\
Euglenophyta & 1 & 2.9 & 1 & 3.1 & 1 & 2.9 & 1 & 3.2 & 1 & 3.7 \\
Total & 34 & & 32 & & 34 & & 31 & & 27 & \\
\hline
\end{tabular}

Table 3 Dimension of dominant species in the experiment.

\begin{tabular}{ll}
\hline Species & Dimension \\
\hline Tetraselmis suecica & Length: $8.4 \mu \mathrm{m}$; width: $4.8 \mu \mathrm{m}$ \\
Tetraselmis chuii & $14-20 \mu \mathrm{m}$ \\
Amphiprora alata & $49 \times 23 \mu \mathrm{m}$ \\
Oscillatoria sp. & $75 \mu \mathrm{m}$ \\
Nitzschia acicularis & Length: $30-100 \mu \mathrm{m}$, width: $3-4 \mu \mathrm{m}$ \\
Nitzschia sigma & Length: $20-68 \mu \mathrm{m}$, width: $3.0-5.0 \mu \mathrm{m}$ \\
Navicula sp. & Length: $32-130 \mu \mathrm{m}$, width: $7-21 \mu \mathrm{m}$ \\
Pleurosigma rectum & Length: $65-75 \mu \mathrm{m}$, width: $16-19 \mu \mathrm{m}$ \\
\hline
\end{tabular}

$50 \%$ total species). Dominant species occurred at 35\% and $60 \%$ and were Peridinium (pyrrophyta), Nitzschia (Bacillariophyta), Tetraselmis, Nanochloropsis (Chlorophyta).

According to Duong, et al. [17], there were 113 algal species which belong to 5 phyla i.e. Bacillariophyta, pyrrophyta, cyanophyta, euglenophyta and chlorophyta found in the white leg shrimp farming area in the Soctrang province, of which Bacillariophyta is dominant species (71 species; $62.83 \%$ ), then euglenophyta (14 species; 12.4\%), cyanophyta (8 species; $7.08 \%$ ), and pyrrophyta and cyanophyta with 10 species $(8.85 \%)$. It was stated that the biodiversity of algae in the shrimp farming area reflected the appropriate environmental conditions e.g. sunlight, salinity, temperature and especially the nutritional conditions of the shrimp ponds.

The algal species of the control, NT30, NT60, NT90, and NT120 were 34, 32, 34, 31, 27, respectively (Table 2). Bacillariophyta is the phylum which occupied the utmost species and varied $45.2-53.1 \%$ in all treatments. In term of biodiversity, there was non-significant difference among treatments observed. 
The appearance of species was recorded in the control, treatment NT30 and NT60 to display diatom as dominant species with high frequency (i.e. day 5 to day 10) such as Nitzschia acicularis, N. sigma, Thalassiosira weissflogii, Navicula sp., Pleurosigma rectum. Besides the two green algae as Tetraselmis suecica and $T$. chuii appeared more frequently. At the mean time, in the treatment of NT90 and NT120, the dominant algae included T. chuii, T. suecica (green alga); Amphiprora alata, Navicula sp., Pleurosigma rectum (diatom); Oscillatoria sp. (blue-green algae); Euglena acus (euglena). Euglena acus appeared at high density from day 9 to day 11 of the NT120, and this is a fact in the relationship with the rich nutrients (i.e. $\mathrm{N}$ and $\mathrm{P}$ ) of this treatment.

Palmer [18] explained that Oscillatoria, Euglena, Scenedesmus, Chlamydomonas, Navicula, Nitzschia, Stigeoclonium and Ankistrodesmus were usually found in polluted water rich in organic compound, and this was agreed also by Gunale and Balakrishnan [19]. Euglena species, however, ranks first the list of 60 species of bio indicators [18].

Table 3 displays within the dominant species, there were only few species with a tiny size such as: Tetraselmis suecica, Tetraselmis chuii, Thalassiosira weissflogii, in which Thalassiosira is an important species in water bodies along the coastline [20] as they are the food for higher feeder of food chain [21]. Unfavorable algae for Artemia in terms of dimension in the same pond may compete for nutrients to the suitable ones. In general, the dominant algal species occurred in the treatment control, NT30 and NT60 to be considered as appropriate algae for Artemia. In opposite, the dominant species in NT90 and NT120 were cyanophyta and euglenophyta and these are not suitable for Artemia filtration.

\section{Conclusion and Recommendation}

Green water created and accelerated by either chicken manure traditionally or by fish meal (low value trash fish) could display to the end with 5 phyla and 38 species, in which bacillariophyta has the highest number of species (i.e. 18 species), then green algae (i.e. 14 species). On the other hand, cyanophyta and euglenophyta were dominant in treatment NT90, NT120 to the end of the experiment; occurring in polluted water (e.g. over N, P elements) was subjected to accelerate algal development in the cyanophyta and euglenophyta. The desired algae were in abundance and appropriate as food for Artemia and included Tetraselmis chuii, Tetraselmis suecica, Nitzschia acicularis, Thalassiosira weissflogii. Out of the other treatments NT30 displayed its highest density $(2,590$ $\times 10^{3}$ cell $/ \mathrm{mL}$ ) which led to the conclusion that fish meal with low value could be replaced to chicken manure, to reduce the organic accumulation in Artemia pond and especially remove the risk when chicken manure was infected from bird-flu disease infection. It is, therefore, recommended that fish meal with a low value at the rate of $30 \mathrm{~g} / \mathrm{m}^{3}$ as organic manure is applied to enhance the wild algae development in green-water ponds for Artemia farming.

\section{References}

[1] Sorgeloos, P. 1980. "Life History of the Brine Shrimp Artemia." In The Brine Shrimp Artemia, Vol. 1, edited by G. Persoone, P. Sorgeloos, O. Roels, and E. Jaspers, Morphology, Genetics, Radiobiology, Toxicology. Universa Press, Wetteren, Belgium, 19-22.

[2] Léger, P., Bengtson, D. A., Simpson, K. L., and Sorgeloos, P. 1986. "The Use and Utritional Value of Artemia as a Food Source." Oceanography and Marine Biology: An Annual Review 24: 521-623.

[3] Sorgeloos, P., Coutteau, P., Dhert, P., Merchie, G., and Lavens, P. 1998. "Use of Brine Shrimp, Artemia spp., in Larval Crustacean Nutrition: A Review." Reviews in Fisheries Science 6: 55-68.

[4] Sorgeloos, P., Dhert, P., and Candreva, P. 2001. "Use of the Brine Shrimp, Artemia spp., in Marine Fish Larviculture." Aquaculture 200: 147-59.

[5] D'Agostino, A. S. 1980. "The Vital Requirements of Artemia, Physiology and Nutrition." In The Brine Shrimp Artemia, Vol. 2, edited by Persoon, G., Sorgeloos, P., Roels, O., Jaspers, E. Physiology, Biochemistry, Molecular Biology, Universa Press, Wetteren, 55-82. 
[6] Van Stappen, G. 1996. "Introduction, Biology and Ecology of Artemia and Use of Cysts." In Manual on the Production and Use of Live Food for Aquaculture, edited by P. Lavens, and P. Sorgeloos, FAO Fisheries Technical Paper 361. Rome, 101-170.

[7] Dhont, J., and Sorgeloos, P. 2002. "Application of Artemia." In ARTEMIA: Basic and Applied Biology, edited by T. J. Abatzopolous, J. A. Beardmore, J. S. Clegg, and P. Sorgeloos. Dordrecht, The Netherlands: Kluwer Academic Publishers, 251-86.

[8] Zmora, O., Avital, E., and Gordin, H. 2002. "Result of an Attempt for Mass Production of Artemia in Extensive Ponds." Aquaculture 213: 395-400.

[9] Nguyen, T. X. T. 1990. "Study on Development of Phytoplankton in Artemia Pond Culture in Vinhchau-Haugiang." M.Sc. thesis, Cantho University.

[10] Nguyen, T. N. A. 2009. "Optimisation of Artemia Biomass Production in Salt Ponds in Vietnam and Use as Feed Ingredient in Local Aquaculture.” PhD thesis, Ghent University, Belgium.

[11] Coutteau, P. 1996. "Microalgae." In Manual on the Production and Use of Live Food for Aquaculture, edited by P. Lavens and P. Sorgeloos, 9-60.

[12] Cheffer, V. B., and Robinson, R. J. 1939. "A Limnological Study of Lake Washington.” Ecol. Monogr. 9: 95-143.

[13] APHA, AWWA, and WEF. 1995. Standard Methods for the Examination of Water and Wastewater, 19th ed., Washington: American Public Health Association.

[14] Nusch, E. A. 1980. "Comparison of Different Methods for Chlorophyll and Phaeopigment Determination." Ergeb. Limnol. 14: 14-36.

[15] Norbert Wasmund, I. T., and Schories, D. 2006. "Optimising the Storage and Extraction of Chlorophyll Samples." Oceanologia 48 (1): 125-44.

[16] Nguyen, V. H., Dang, K. T., Nguyen, T. N. A., Nguyen, T. H. V., Truong, C. L., and Pham, T. T. N. 2014. "Influence of Salinity on the Formation and Development of Biofloc in Fertilizer Pond." Can Tho Uni. J. Sci. 30 : 53-63.

[17] Duong, T. H. O., Huynh, T. G., and Nguyen, T. K. Li. 2014. "Relationship of Shrimp Health and Fluctuation of Phytoplankton in Intensive White Leg (Litopeneus vannamei) Shrimp Pond." Can Tho Uni. J. Sci. Aquaculture issue :159-68.

[18] Palmer, C. M. 1969. "Composite Rating of Algae Tolerating Organic Pollution." Journal of Phycology 5: 78-82.

[19] Gunale, V. R., and Balakrishnan, M. S. 1981. "Biomonitoring of Eutrophication in the Pavana, Mula \& Mutharivers Flowing through Poona." Indian Journal of Environmental Health 23: 316-22.

[20] Ryther, J. H., and Officer, C. B. 1981. "Impact of Nutrient Enrichment on Water Uses." In Estuaries and Nutrients, edited by B. J. Neilson, and L. E. Cronin. Totawa, NJ: Humana Press Inc., pp. 247-62.

[21] Boyd, C. E. 1990. Water Quality in Ponds for Aquaculture. Auburn University, Alburn AL, USA.

[22] Alabama Agricultural Experiment Station, Auburn University, Auburn University, Ala, 1990. 